\title{
Effects of interactions between common genetic variants and smoking on colorectal cancer
}

\author{
Nan Song ${ }^{1}$, Aesun Shin ${ }^{1,2,3^{*+}} \mathbb{D}$, Hye Soo Jung ${ }^{1}$, Jae Hwan $\mathrm{Oh}^{4}$ and Jeongseon Kim ${ }^{3,5^{*+}}$
}

\begin{abstract}
Background: Although genome-wide association studies (GWAS) have identified variants in approximately 40 susceptibility loci for colorectal cancer (CRC), there are few studies on the interactions between identified single-nucleotide polymorphisms (SNPs) and lifestyle risk factors. We evaluated whether smoking could modify associations between these genetic variants and CRC risk.
\end{abstract}

Methods: A total of 703 CRC patients and 1406 healthy controls were included in this case-control study from the National Cancer Center in Korea. Thirty CRC susceptibility SNPs identified in previous GWAS were genotyped. A logistic regression model was used to examine associations between the SNPs and smoking behaviors by sex. The interaction was estimated by including an additional interaction term in the model.

Results: In men, an increased CRC risk was observed for longer durations $\left(\mathrm{OR}_{>28}\right.$ vs. $\leq 28$ years $=1.49$ $(95 \% \mathrm{Cl}=1.11-1.98))$, greater quantities $\left(\mathrm{OR}_{\geq 20}\right.$ vs. <20cigarettes/day $\left.=2.12(1.61-2.79)\right)$, and longer pack-years of smoking $\left(\mathrm{OR}_{\geq 21}\right.$ vs. $<21$ pack-years $\left.=1.78(1.35-2.35)\right)$. In women, longer pack-years of smoking significantly increased $C R C$ risk $\left(O R_{\geq 5}\right.$ vs. $<5$ pack-years $\left.=6.11(1.10-34.00)\right)$. Moreover, there were significant interactions between smoking status and the polymorphisms rs1957636 at $14 \mathrm{q} 22.3\left(P_{\text {interaction }}=5.5 \times 10^{-4}\right)$ and rs4813802 at 20p12.3

$\left(P_{\text {interaction }}=0.04\right)$ in men. Interactions between smoking status and the rs6687758 at $1 \mathrm{q} 41\left(P_{\text {interaction }}=0.03\right)$, duration and the rs174537 at 11q12.2 $\left(P_{\text {interaction }}=0.05\right)$, and pack-years and the rs4813802 $\left(P_{\text {interaction }}=0.04\right)$ were also found in women.

Conclusions: Associations between susceptibility SNPS and CRC risk may be modified by smoking behaviors, supporting the existence of gene-smoking interactions.

Keywords: Colorectal cancer, Gene-environment interaction, Smoking behaviors, Single-nucleotide polymorphism, Case-control study

\section{Background}

Smoking is known to cause many forms of cancer that affect the respiratory, digestive, and urinary tracts [1]. Cigarette smoke contains more than 60 different carcinogenic compounds, including polycyclic aromatic hydrocarbons (PAH), nitrosamines, and aromatic amines, which can form DNA adducts by metabolic activation.

\footnotetext{
* Correspondence: shinaesun@snu.ac.kr; jskim@ncc.re.kr

${ }^{\dagger}$ Equal contributors

${ }^{1}$ Cancer Research Institute, Seoul National University College of Medicine, Seoul, South Korea

${ }^{3}$ Molecular Epidemiology Branch, National Cancer Center, Goyang, South Korea

Full list of author information is available at the end of the article
}

This can lead to mutations in tumor-suppressor genes and oncogenes, as well as cell damage, resulting in tumor development [2]. Because carcinogens from smoking can also reach the colorectal mucosa and affect the expression of cancer-related genes [3], it has been established that cigarette smoking is associated with an increased risk of colorectal cancer (CRC) with sufficient evidence by the International Agency of Research on Cancer [4].

Previous studies have reported that cigarette smoke interacts with genetic factors, suggesting that different risk estimates apply to different genetic predispositions [5]. However, there remains a lack of research on gene and 
smoking interactions for CRC because most studies have focused on genetic polymorphisms of tobacco metabolizing enzymes, and only a weak $m E H 3$-smoking interaction effect was found by a meta-analysis [5]. Genome-wide association studies (GWAS) have identified a number of common low-penetrance genetic loci involved in the etiology and progression of CRC [6], but there were few gene-environment interaction studies between GWAS-identified SNPs and smoking [7]. The genome-wide interaction analyses between genetic variants and smoking were also conducted, but none of statistically significant interactions were observed $[8,9]$.

Although none of GWAS-identified SNPs were directly relevant to tobacco metabolizing enzymes, since the smoking has been the most environmental exposure factors affecting gene-environment interactions in cancer [10] and both of GWAS-identified SNPs and smoking are evident risk factors for CRC, there may be possible indirect gene-environment interactions. In this case-control study, we hypothesized that smoking could modify associations between common genetic variants and CRC risk. To test this hypothesis, we examined the effects of associations between smoking behaviors and 30 susceptibility SNPs, which were previously identified by GWAS, on CRC risk. Interactions between smoking behaviors and the genotypes of the susceptibility SNPs were also investigated.

\section{Methods}

\section{Study population}

Eligible cases included CRC patients who were newly diagnosed and underwent surgical treatment between August 2010 and August 2013 at the National Cancer Center (NCC) in Korea. Among 1427 eligible CRC patients, we were able to contact 1259 patients, and 1070 patients agreed to participate in this study. Among them, 367 patients did not complete our questionnaire and had insufficient blood samples for genotyping; these patients were excluded. Accordingly, a total of 703 CRC patients were included in the analysis. Healthy controls were recruited from a cancerscreening center at the NCC among people who visited for a health check-up program supported by the National Health Insurance Corporation between October 2007 and December 2014. After selecting individuals who completed the questionnaire and had sufficient blood samples, the remaining control subjects were 1:2 frequency-matched to 703 CRC patients according to 5-year interval age and sex. Thus, a total of 703 cases and 1406 controls were included in the analysis. The study was approved by the institutional review board of the NCC (IRB No. NCCNCS-10-350 and NCC 2015-0202).

\section{Data collection}

The CRC patients were face-to-face interviewed by trained interviewers using a structured and written questionnaire (Additional file 1), which was also used in previous studies [11-13]. The original questionnaire written in Korean was developed based on questionnaires of the Korean National Health and Nutrition Examination survey (KNHANES) and the quality assurance and control of the national survey was described in elsewhere [14]. From the questionnaire, we obtained general information on age, sex, family history of CRC, body mass index, education level, and lifestyle information, including alcohol drinking and smoking behavior. The control participants completed self-administered questionnaires on general and lifestyle information. Then, the trained interviewers called them to validate their responses.

Smoking behaviors consisted of ever smoking status, smoking duration, amount of smoking, and pack-years of smoking. The smoking status was classified as never and ever smokers which were defined as those who had smoked $\geq 5$ packs of cigarettes during their lifetime. The pack-years of smoking were calculated by multiplying the amount of smoking (number of cigarettes per day) by duration (number of years smoked) and dividing by 20. The duration, amount, pack-years of smoking was divided into two groups by median value among ever smokers to conduct the gene-environment interaction analyses.

\section{Genotyping}

From the National Human Genome Research Institute (NHGRI) GWAS Catalog [6], we extracted 41 CRCassociated SNPs with $p$-value $<5 \times 10^{-8}$ reported before 2015. Among those SNPs, 14 imputed SNPs were excluded and 9 SNPs were additionally identified through reference review. The 36 susceptibility SNPs were located among 27 loci, which have been identified to be associated with CRC risk by previous GWAS. These SNPs were selected for genotyping (Additional file 2: Table S1) [15-25]. From the subjects' blood samples, genomic DNA was extracted using a MagAttract DNA Blood M48 kit and BioRobot M48 automatic extraction equipment (Qiagen, Hilden, Germany) according to the manufacturer's instructions. The genotyping was performed using an Agenabio MassArray iPLEX ${ }^{\bullet}$ gold assay (Agena Bioscience, Inc., San Diego, CA, US). Because of genotyping failure for 4 SNPs and a monomorphic genotype for 2 SNPs, 30 of the originally selected 36 SNPs were included in the final analysis (Additional file 2: Table S2).

\section{Statistical analysis}

The Hardy-Weinberg equilibrium (HWE) was tested for the genotypes of each SNP using a chi-square test for the controls. To compare characteristics between the 
cases and the controls, a t-test was used for continuous variables, specifically age and body mass index (BMI), and a chi-square test was used for categorical variables, specifically family history of CRC, education level, alcohol drinking, and smoking status. The associations of smoking behaviors and additive SNPs on CRC risk were examined using a logistic regression model that was adjusted for age, family history of CRC, BMI, and education level. The interactions were estimated by including additional interaction (genotypes of each SNP $\times$ smoking behaviors) terms in the logistic models. In terms of the statistically significant interactions, we also assessed associations between SNPs and CRC risk after stratification by smoking behavior. For multiple comparisons of the 30 SNPs, false discovery rate (FDR) and Bonferroni tests were additionally conducted. For all association tests, odds ratios (ORs) and 95\% confidence intervals (95\% CIs) were calculated, and $p$-values less than 0.05 were considered statistically significant. All statistical analyses were stratified by sex and considered two-sided; analyses were performed using SAS version 9.3 (SAS Institute, Inc., Cary, NC, US).

\section{Results}

The characteristics of the study subjects are summarized by sex in Table 1 . Because of the frequency matching by age and sex between the cases and the controls, there was no significant difference in age. For the men, those affected by CRC showed a higher frequency of having a family history of CRC $(P<0.01)$, a higher BMI $(P<0.01)$, and a lower education level $(P<0.01)$ than the healthy controls. However, alcohol drinking and smoking statuses were similar among the male CRC patients and the control subjects. For the women, there were no differences in family history of CRC, BMI, or alcohol drinking status, but the CRC patients were more likely to have a lower education level $(P<0.01)$ and more smoking experience than the controls $(P<0.01)$.

Table 2 shows the adjusted associations between smoking behaviors and risk of CRC. The male CRC patients who smoked for more than 28 years $(\mathrm{OR}=1.49,95 \%$ $\mathrm{CI}=1.11-1.98, P<0.01)$ at an amount equal or greater than 20 cigarettes per day $(\mathrm{OR}=2.12,95 \% \mathrm{CI}=1.61-2.79$, $P<0.01)$ and who smoked for equal or greater than 21 pack-years $(\mathrm{OR}=1.78,95 \% \mathrm{CI}=1.35-2.35, P<0.01)$ were significantly associated with increased risk of CRC. For the women, we found that ever smoking $(\mathrm{OR}=2.23,95 \%$ $\mathrm{CI}=1.15-4.34, P=0.02)$ and smoking duration equal or greater than 5 pack-years were associated with increased risk of $\mathrm{CRC}(\mathrm{OR}=6.11,95 \% \mathrm{CI}=1.10-34.00, P=0.04)$.

The associations that were defined between the previously identified common SNPs and the risk of CRC were stratified by sex and provided in Additional file 2: Table S2. We found 5 significant interactions between the common SNPs and the various smoking behaviors assessed for risk of CRC (Table 3). There was an

Table 1 Characteristics of colorectal cancer cases and controls from National Cancer Center in Korea, 2010-2013

\begin{tabular}{|c|c|c|c|c|c|c|c|c|c|c|}
\hline \multirow[t]{3}{*}{ Characteristics } & \multicolumn{5}{|l|}{ Men } & \multicolumn{5}{|c|}{ Women } \\
\hline & \multicolumn{2}{|c|}{$\begin{array}{l}\text { Case } \\
(N=480)\end{array}$} & \multicolumn{2}{|c|}{$\begin{array}{l}\text { Control } \\
(N=960)\end{array}$} & \multirow[t]{2}{*}{$P^{a}$} & \multicolumn{2}{|c|}{$\begin{array}{l}\text { Case } \\
(N=223)\end{array}$} & \multicolumn{2}{|c|}{$\begin{array}{l}\text { Control } \\
(N=446)\end{array}$} & \multirow[t]{2}{*}{$P^{a}$} \\
\hline & $\mathrm{N}$ & $(\%)$ & $\mathrm{N}$ & $(\%)$ & & $\mathrm{N}$ & $(\%)$ & $\mathrm{N}$ & (\%) & \\
\hline Age (years), mean (SD) & 57.0 & (9.3) & 56.5 & $(8.9)$ & 0.34 & 55.1 & (9.8) & 54.8 & (9.4) & 0.68 \\
\hline Family history of colorectal cancer ${ }^{\mathrm{b}}$ & & & & & $<0.01$ & & & & & 0.21 \\
\hline no & 439 & $(91.5)$ & 919 & $(95.7)$ & & 215 & $(96.4)$ & 420 & $(94.2)$ & \\
\hline yes & 41 & $(8.5)$ & 41 & $(4.3)$ & & 8 & (3.6) & 26 & (5.8) & \\
\hline BMI $\left(\mathrm{kg} / \mathrm{m}^{2}\right)$, mean $(\mathrm{SD})$ & 23.7 & $(3.0)$ & 24.4 & $(2.6)$ & $<0.01$ & 23.8 & $(4.2)$ & 23.2 & (2.8) & 0.10 \\
\hline Education level & & & & & $<0.01$ & & & & & $<0.01$ \\
\hline$\leq$ middle school & 151 & $(31.5)$ & 128 & $(13.3)$ & & 104 & $(46.6)$ & 69 & (15.5) & \\
\hline$\leq$ high school & 194 & $(40.4)$ & 260 & $(27.1)$ & & 75 & (33.6) & 197 & $(44.2)$ & \\
\hline$\geq$ college or university & 135 & $(28.1)$ & 562 & $(58.5)$ & & 44 & $(19.7)$ & 179 & $(40.1)$ & \\
\hline Alcohol drinking & & & & & 0.19 & & & & & 0.24 \\
\hline never & 88 & $(18.3)$ & 150 & $(15.6)$ & & 124 & (55.6) & 269 & $(60.3)$ & \\
\hline ever & 392 & $(81.7)$ & 810 & $(84.4)$ & & 99 & $(44.4)$ & 177 & (39.7) & \\
\hline Smoking & & & & & 0.06 & & & & & $<0.01$ \\
\hline never & 116 & $(24.2)$ & 191 & $(19.9)$ & & 200 & (89.7) & 426 & (95.5) & \\
\hline ever & 364 & $(75.8)$ & 769 & $(80.1)$ & & 23 & $(10.3)$ & 20 & $(4.5)$ & \\
\hline
\end{tabular}

Abbreviations: SD standard deviation

${ }^{a}$ T-test for continuous variables and chi-square test for categorical variables

${ }^{b}$ First- and/or second-degree relatives with colorectal cancer 
Table 2 Association between smoking behaviors and risk of colorectal cancer

\begin{tabular}{|c|c|c|c|c|c|c|c|c|c|c|c|c|c|c|}
\hline \multirow[t]{3}{*}{ Smoking behavior } & \multicolumn{7}{|c|}{ Men } & \multicolumn{7}{|c|}{ Women } \\
\hline & \multicolumn{2}{|c|}{$\begin{array}{l}\text { Case } \\
(N=480)\end{array}$} & \multicolumn{2}{|c|}{$\begin{array}{l}\text { Control } \\
(N=960)\end{array}$} & \multirow[t]{2}{*}{ OR } & \multirow[t]{2}{*}{$(95 \% \mathrm{Cl})^{\mathrm{a}}$} & \multirow[t]{2}{*}{$P$} & \multicolumn{2}{|c|}{$\begin{array}{l}\text { Case } \\
(N=223)\end{array}$} & \multicolumn{2}{|c|}{$\begin{array}{l}\text { Control } \\
(N=446)\end{array}$} & \multirow[t]{2}{*}{ OR } & \multirow[t]{2}{*}{$(95 \% \mathrm{Cl})^{\mathrm{a}}$} & \multirow[t]{2}{*}{$P$} \\
\hline & $\bar{N}$ & (\%) & $\bar{N}$ & (\%) & & & & $\overline{\mathrm{N}}$ & (\%) & $\overline{\mathrm{N}}$ & (\%) & & & \\
\hline \multicolumn{15}{|l|}{ Smoking status } \\
\hline never smoker & 116 & $(24.2)$ & 191 & $(19.9)$ & 1.00 & (ref.) & & 200 & $(89.7)$ & 426 & $(95.5)$ & 1.00 & (ref.) & \\
\hline ever (ex- and current) smoker & 364 & $(75.8)$ & 769 & $(80.1)$ & 0.75 & $(0.56-1.00)$ & 0.05 & 23 & $(10.3)$ & 20 & $(4.5)$ & 2.23 & $(1.15-4.34)$ & 0.02 \\
\hline \multicolumn{15}{|l|}{ Smoking duration ${ }^{\mathrm{b}}$, years (median) } \\
\hline$\leq 28$ in men, $\leq 15$ in women & 164 & $(45.1)$ & 422 & $(54.9)$ & 1.00 & (ref.) & & 8 & $(34.8)$ & 14 & $(70.0)$ & 1.00 & (ref.) & \\
\hline$>28$ in men, > 15 in women & 200 & $(55.0)$ & 347 & $(45.1)$ & 1.49 & $(1.11-1.98)$ & $<0.01$ & 15 & $(65.2)$ & 6 & $(30.0)$ & 4.82 & $(0.97-24.03)$ & 0.05 \\
\hline \multicolumn{15}{|l|}{$\begin{array}{l}\text { Amount of smoking }{ }^{b}, \\
\text { cigarettes per day (median) }\end{array}$} \\
\hline$<20$ in men, $<8$ in women & 123 & (33.8) & 419 & $(54.5)$ & 1.00 & (ref.) & & 9 & (39.1) & 13 & $(65.0)$ & 1.00 & (ref.) & \\
\hline$\geq 20$ in men, $\geq 8$ in women & 241 & $(66.2)$ & 350 & $(45.5)$ & 2.12 & $(1.61-2.79)$ & $<0.01$ & 14 & $(60.9)$ & 7 & $(35.0)$ & 3.43 & $(0.73-16.06)$ & 0.12 \\
\hline \multicolumn{15}{|l|}{$\begin{array}{l}\text { Pack-years of smoking }{ }^{b}, \\
\text { pack-years (median) }\end{array}$} \\
\hline$<21$ in men, $<5$ in women & 134 & $(36.8)$ & 418 & $(54.4)$ & 1.00 & (ref.) & & 7 & $(30.4)$ & 12 & $(60.0)$ & 1.00 & (ref.) & \\
\hline$\geq 21$ in men, $\geq 5$ in women & 230 & (63.2) & 351 & $(45.6)$ & 1.78 & $(1.35-2.35)$ & $<0.01$ & 16 & (69.6) & 8 & $(40.0)$ & 6.11 & $(1.10-34.00)$ & 0.04 \\
\hline
\end{tabular}

Abbreviations: OR odds ratio, $\mathrm{Cl}$ confidence interval, and ref. reference

aLogistic regression model adjusted for age, family history of colorectal cancer, BMI, and education level

${ }^{\mathrm{b}}$ Smoking behaviors among ever smokers

interaction between smoking status and the polymorphism rs1957636 at 14q22.3 in LOC105370507 for CRC risk in men. The risk allele $(C)$ was associated with decreased risk among never smokers $\left(\mathrm{OR}_{\mathrm{CC} \text { vs. } \mathrm{TT}}=0.36,95 \% \mathrm{CI}=0.16-0.79, \mathrm{OR}_{\mathrm{CT}+\mathrm{CC} \text { vs. }}\right.$ $\mathrm{TT}=0.54,95 \% \mathrm{CI}=0.32-0.92)$ and increased risk among ever smokers $\left(\mathrm{OR}_{\mathrm{CC}}\right.$ vs. $\mathrm{TT}=1.51,95 \% \mathrm{CI}=$ $1.02-2.24, \mathrm{OR}_{\mathrm{CT}+\mathrm{CC} \text { vs. TT }}=1.33,95 \% \mathrm{CI}=1.00-1.77$, $P_{\text {interaction }}$ for additive model $=5.5 \times 10^{-4}, P_{\text {interaction }}$ for dominant model $\left.=1.9 \times 10^{-3}\right)$, with a statistically significant FDR-corrected $p$-value $\left(P_{\text {interaction for additive model }}\right.$ adjusted by $\left.\mathrm{FDR}=1.8 \times 10^{-3}\right)$. A significant interaction was observed between smoking status and the polymorphism rs4813802 at 20p12.3. This allele was associated with a lower risk of CRC among ever smokers in men $\left(\mathrm{OR}_{\mathrm{GG}}\right.$ vs. TT $=0.41,95 \% \mathrm{CI}=0.18-0.94, P_{\text {interaction for }}$ additive model $=0.04)$. In women, significant interactions were observed between smoking status and the polymorphism rs6687758 at $1 \mathrm{q} 41\left(P_{\text {interaction for additive model }}=\right.$ $0.03)$, smoking duration and the polymorphism rs 174537 at $11 \mathrm{q} 12.2$ in $\operatorname{MYRF}\left(P_{\text {interaction for additive model }}=0.05\right)$, and pack-years of smoking and the polymorphism rs 4813802 $\left(P_{\text {interaction for additive model }}=0.04\right)$, but there were no statistically significant associations between those interactions and risk of CRC.

\section{Discussion}

In this case-control study, we found that various smoking behaviors, including smoking status, smoking duration, amount of smoking, and pack-years of smoking, were associated with risk of CRC. Additionally, we found that associations between several common susceptibility SNPs, including rs1957636 at 14q22.3, rs4813802 at 20p12.3, rs6687758 at $1 \mathrm{q} 41$, and rs174537 at 11q12.2, and risk of CRC were modified by smoking behaviors according to sex.

In this study, greater durations, amounts, and packyears of smoking in men and ever status and greater pack-years of smoking in women were all associated with an increased risk of CRC. A previous meta-analysis also showed an association between smoking and CRC risk in both men and women [26]. Several studies, in contrast, have reported that associations between smoking and CRC risk were attenuated in women due to small sample sizes or the anti-estrogenic effect of smoking [27, 28].

Biological evidence on the association between smoking and CRC has suggested that carcinogenic compounds absorbed from cigarette smoking could cause mutations in the APC or KRAS genes that are known to be related to early stages of colorectal carcinogenesis [29]. It was reported that $A P C$ and KRAS mutations in colorectal polyps were more frequent among smokers compared to non-smokers [30]. However, there were also inconsistent results on the roles of APC and KRAS mutations induced by cigarette smoking in CRC [31] as well as a lack of similar studies. Therefore, more studies on the molecular mechanisms that cause genetic damage induced by cigarette smoking in CRC are needed. 
Table 3 Association of GWAS-identified single-nucleotide polymorphisms on risk of colorectal cancer by smoking behaviors

\begin{tabular}{|c|c|c|c|c|c|c|c|c|c|c|c|c|c|c|}
\hline \multirow[t]{2}{*}{ SNP/genotype } & \multicolumn{2}{|c|}{ Case } & \multicolumn{2}{|c|}{ Control } & \multirow[t]{2}{*}{$\mathrm{OR}^{\mathrm{a}}$} & \multirow[t]{2}{*}{$(95 \% \mathrm{Cl})$} & \multicolumn{2}{|c|}{ Case } & \multicolumn{2}{|c|}{ Control } & \multirow[t]{2}{*}{$\mathrm{OR}^{\mathrm{a}}$} & \multirow[t]{2}{*}{$(95 \% \mathrm{Cl})$} & \multirow[t]{2}{*}{$P_{\text {interaction }}^{\mathrm{b}}$} & \multirow[t]{2}{*}{ FDR-corrected $P_{\text {interaction }}$} \\
\hline & $\mathrm{N}$ & $(\%)$ & $\mathrm{N}$ & $(\%)$ & & & $\mathrm{N}$ & $(\%)$ & $\mathrm{N}$ & $(\%)$ & & & & \\
\hline \multicolumn{15}{|l|}{$\overline{M e n}$} \\
\hline Smoking status x rs 1957636 & \multicolumn{6}{|c|}{ never smoker $(N=307)$} & \multicolumn{6}{|c|}{ ever smoker $(N=1133)$} & & \\
\hline$\pi$ & 47 & $(40.5)$ & 54 & (28.3) & 1.00 & (ref.) & 113 & $(31.0)$ & 285 & $(37.1)$ & 1.00 & (ref.) & $5.5 \times 10^{-4}$ & $1.8 \times 10^{-3}$ \\
\hline $\mathrm{CT}$ & 54 & $(46.6)$ & 100 & (52.4) & 0.62 & $(0.35-1.08)$ & 178 & $(48.9)$ & 364 & $(47.3)$ & 1.27 & $(0.94-1.72)$ & & \\
\hline CC & 14 & $(12.1)$ & 37 & (19.4) & 0.36 & $(0.16-0.79)$ & 70 & $(19.2)$ & 118 & (15.3) & 1.51 & $(1.02-2.24)$ & & \\
\hline$C T+\pi$ & 68 & (58.6) & 137 & (71.7) & 0.54 & $(0.32-0.92)$ & 248 & $(68.1)$ & 482 & (62.7) & 1.33 & $(1.00-1.77)$ & $1.9 \times 10^{-3}$ & 0.06 \\
\hline Smoking status x rs4813802 & \multicolumn{6}{|c|}{ never smoker $(N=307)$} & \multicolumn{6}{|c|}{ ever smoker $(N=1133)$} & & \\
\hline$\pi$ & 61 & (52.6) & 123 & $(64.4)$ & 1.00 & (ref.) & 222 & $(61.0)$ & 463 & $(60.2)$ & 1.00 & (ref.) & 0.04 & 0.55 \\
\hline GT & 42 & $(36.2)$ & 50 & $(26.2)$ & 1.72 & $(0.98-3.01)$ & 124 & $(34.1)$ & 254 & (33.0) & 1.00 & $(0.75-1.33)$ & & \\
\hline GG & 7 & $(6.0)$ & 8 & $(4.2)$ & 1.27 & $(0.40-4.06)$ & 8 & (2.2) & 37 & (4.8) & 0.41 & $(0.18-0.94)$ & & \\
\hline $\mathrm{GT}+\mathrm{GG}$ & 49 & $(42.2)$ & 58 & (30.4) & 1.65 & $(0.97-2.81)$ & 132 & (36.3) & 291 & (37.8) & 0.92 & $(0.70-1.22)$ & 0.05 & 0.46 \\
\hline \multicolumn{15}{|l|}{ Women } \\
\hline Smoking status x rs6687758 & \multicolumn{6}{|c|}{ never smoker $(N=626)$} & \multicolumn{6}{|c|}{ ever smoker $(N=43)$} & & \\
\hline AA & 100 & $(50.0)$ & 185 & $(43.4)$ & 1.00 & (ref.) & 10 & $(43.5)$ & 8 & $(40.0)$ & 1.00 & (ref.) & 0.03 & 0.34 \\
\hline AG & 69 & (34.5) & 177 & (41.6) & 0.71 & $(0.47-1.06)$ & 7 & (30.4) & 9 & $(45.0)$ & 1.05 & $(0.20-5.54)$ & & \\
\hline GG & 9 & (4.5) & 31 & (7.3) & 0.49 & $(0.21-1.15)$ & 5 & $(21.7)$ & 0 & $(0.0)$ & - & & & \\
\hline$A G+G G$ & 78 & $(39.0)$ & 208 & (48.8) & 0.68 & $(0.46-0.99)$ & & & & & 1.86 & $(0.38-9.20)$ & 0.24 & 0.53 \\
\hline Smoking duration ${ }^{c}$ x rs174537 & \multicolumn{6}{|c|}{$\leq 15$ years $(N=22)$} & \multicolumn{6}{|c|}{$>15$ years $(N=21)$} & & \\
\hline GG & 3 & $(37.5)$ & 4 & (28.6) & 1.00 & (ref.) & 7 & $(46.7)$ & 4 & $(66.7)$ & 1.00 & (ref.) & 0.05 & 0.51 \\
\hline GT & 2 & (25.0) & 7 & $(50.0)$ & 1.42 & $(0.05-41.81)$ & 5 & (33.3) & 2 & (33.3) & 0.30 & $(0.01-12.01)$ & & \\
\hline$\pi$ & 3 & $(37.5)$ & 0 & $(0.0)$ & - & & 2 & (13.3) & 0 & $(0.0)$ & - & & & \\
\hline $\mathrm{GT}+\pi$ & 5 & (62.5) & 7 & $(50.0)$ & 8.55 & $(0.68-107.61)$ & 7 & $(46.7)$ & 2 & (33.3) & 0.36 & $(0.01-14.35)$ & 0.15 & 0.99 \\
\hline $\begin{array}{l}\text { Pack-years of } \\
\text { smoking }^{c} \text { x rs4813802 }\end{array}$ & \multicolumn{6}{|c|}{$<5$ pack-years $(N=19)$} & \multicolumn{6}{|c|}{$\geq 5$ pack-years $(N=24)$} & & \\
\hline$\pi$ & 5 & (71.4) & 7 & (58.3) & 1.00 & (ref.) & 8 & $(50.0)$ & 6 & (75.0) & 1.00 & (ref.) & 0.04 & 0.57 \\
\hline GT & 2 & (28.6) & 5 & $(41.7)$ & 0.48 & $(0.02-13.68)$ & 7 & $(43.8)$ & 2 & (25.0) & 20.42 & $(0.84-499.17)$ & & \\
\hline GG & 0 & $(0.0)$ & 0 & $(0.0)$ & - & & 1 & (6.3) & 0 & $(0.0)$ & - & & & \\
\hline $\mathrm{GT}+\mathrm{GG}$ & 2 & (28.6) & 5 & $(41.7)$ & 0.48 & $(0.02-13.68)$ & 8 & $(50.0)$ & 2 & (25.0) & 23.17 & $(0.96-559.14)$ & 0.03 & 0.48 \\
\hline
\end{tabular}

Abbreviations: GWAS genome-wide association study, SNP single-nucleotide polymorphism, OR odds ratio, $C I$ confidence interval, and FDR false-discovery rate aLogistic regression model adjusted for age, family history of CRC, BMI, and education level

bLogistic regression model including interaction term (smoking behavior $\times$ genotypes for SNP)

'Smoking behaviors among ever smokers

Previous studies on gene and smoking interactions in CRC have been based on candidate genes such as CYP1A1 [32], CYP1A2 [32], GPX1 [33], GSTM1 [32, 34-38], GSTT1 [35-38], LEPR [39], MAD1L1 [40], mEH3 [41], mEH4 [41], NAT1 [36], NAT2 [32, 42, 43], NQO1 [44], OGG1 [33], PTEN [45], SMAD7 [46], and TGFBR1 [46]. A meta-analysis reported no evidence for gene and smoking interactions for the GSTM1, GSTT1, $m E H 3, m E H 4$, and NAT2 genes in CRC. However, this study suggested a potential negative interaction between smoking and $m E H 3$ in colorectal adenoma (CRA). There was also a potential positive interaction between smoking and GSTT1 because smoking was associated with risk of CRA only among GSTT1-null carriers [5].

In this study, we identified novel interactions between smoking behaviors and common susceptibility SNPs, specifically rs1957636, rs4813802, rs6687758, rs174537, and rs481302, in CRC according to sex. The most significant interaction was between smoking status and rs1957636 and showed variable effects: allele (C) was associated with decreased or increased risk of CRC according to whether an individual was a never or ever smoker. The SNP rs1957636 is located at $14 \mathrm{q} 22.3$ (LOC105370507) and is close to the transcription start site of the BMP4 gene, which is involved in bone morphogenetic protein (BMP) signaling. A similar positive interaction was also observed between rs17563 on BMP4 and smoking for CRC risk in a previous study [47] in spite of little linkage disequilibrium between rs1957636 and rs17563 $\left(r^{2}=0.12\right.$ in HapMap3 JPT + $\mathrm{CHB}+\mathrm{CHD}$ individuals). Biologically, BMP signaling has been suggested to cause human cancer through its 
tumor suppressor properties, but colon cancer cells were resistant to the growth suppression and differentiation induced by BMP4 [48]. Experiments conducted using a rat model showed that BMP4 was up-regulated by chronic cigarette smoking [49]. Thus, it is possible that the interaction between BMP4 and smoking might explain the variable effects of $B M P 4$ on the risk of CRC.

For the male subjects, the $G$ allele of the SNP rs4813802 tended to be associated with risk of CRC among the ever smokers, while no associations with the SNP were observed among the subjects who never smoked. A possible interaction between the SNP rs4813802 and smoking on CRC risk was also observed in women. The SNP rs4813802 is located upstream of the $B M P 2$ gene. Previous experiments have found that higher nicotine concentrations in smokers decreased BMP2 expression [50], which could mediate intestinal cell growth [51]. Furthermore, the $B M P 2$ gene is part of the transforming growth factor- $\beta$ (TGF $\beta$ ) superfamily and plays a role in cell apoptosis, differentiation, and proliferation [52]. However, no results were reported on interactions between SNPs on BMP2 and smoking behaviors in CRC risk. More studies on BMP pathway loci, including BMP4 and BMP2, should be conducted to explain the missing heritability of CRC [53].

Smoking behaviors also possibly interacted with the polymorphisms rs6687758 at 1q41 (intergenic) and rs174537 at 11q12.2 (MYRF) in women, despite the lack of associations with CRC risk. Of these SNPs, rs6687758 is near the DUSP10 gene, which encodes dual specificity phosphatase 10 (DUSP10). DUSP10 regulates intestinal epithelial cell proliferation through the mitogenactivated protein kinase (MAPK) signaling pathway, thereby acting as a suppressor of CRC [54]. The polymorphism rs174537 is known as an expression quantitative trait locus (eQTL) for the FADS1 and FADS2 genes [22], which encode enzymes involved in the metabolism of polyunsaturated fatty acids and mediate the effects of cyclooxygenase-2 (COX-2) in CRC carcinogenesis. Benzo[a]pyrene, one of the carcinogenic compounds included in cigarette smoke, up-regulated COX-2 in mouse cells [55], which in turn could either activate or be dependent on the MAPK pathway, suggesting a possible effect resulting from a gene-smoking interaction $[55,56]$.

One of the strengths of this study is that we found novel interactions between genes and smoking behaviors that affected CRC risk, accounting for part of the missing heritability in previous GWAS. Especially, the novel interaction between smoking status and the additive genotypes of the polymorphism rs1957636 $\left(P_{\text {interaction }}=5.5 \times 10^{-4}\right)$ was still significant after FDR (adjusted $P_{\text {interaction }}=1.8 \times 10^{-3}$ ) and Bonferroni adjustments $\left(P_{\text {interaction }}<1.67 \times 10^{-3}\right)$. Although several gene-environment interactions involving susceptibility loci identified in GWAS have been evaluated [7, 9, 57-60], no significant gene-smoking interactions have been observed. In addition, this study considered various types of information regarding smoking behavior, such as status, duration, amount, and pack-years of smoking, which differs from most previous gene-smoking interaction studies, which have typically dealt only with smoking status.

A limitation of this study is the insufficient sample size, leading to relatively low statistical power for detecting gene-smoking interactions; a power of 0.66 was found for the additive and dominant models of the SNP rs1957636, with an $\alpha=0.05$ in men. To obtain a power over 0.80 for the same condition, a minimum male sample size of 2025 would be recommended. In our analyses of ever smokers, the median values of duration, amount, and pack-years of smoking were defined differently depending on sex. When we analyzed the data using the common median values between the men and the women, the female associations between smoking behaviors and CRC risk were not supportive of further calculations due to the small number of ever smokers. For women, smoking prevalence is very low in Korea [61]. Accordingly, even though we used the female-specific median values for smoking behaviors, several associations between each combination of genotype and smoking behavior and CRC risk could not be calculated.

Another limitation is that this hospital-based casecontrol study might have had selection bias because the control subjects were recruited from among individuals who took a health examination. However, the control subjects were from the same hospital as the cases, and random sampling and matching with the cases were conducted to reduce the effect of selection bias. Nevertheless, several GWAS-identified SNPs had a higher proportion of risk alleles in controls than in cases. This may be due to ethnic differences in allele frequency of SNPs and potential lack of representativeness of controls who visited hospital for medical-check-up. However, family history of CRC was not that frequent in controls and if controls were actually characterized by higher-risk group for CRC compared to general population, the results would have been estimated towards the null.

Moreover, other potential confounders, such as dietary factors, were not adjusted in the analyses since there were very little difference in the results. Lastly, because we examined SNPs previously identified in GWAS in this analysis, we did not cover or represent all polymorphisms related to CRC risk. GWAS are likely to identify functional genetic variants that are associated with CRC development rather than those correlated with direct disease-causing function. Accordingly, additional fine mapping and functional studies on possible gene-environment interactions should be conducted. 


\section{Conclusions}

In conclusion, this study provided evidence that smoking could be associated with CRC risk and identified associations between several common susceptibility SNPs, namely, rs1957636 at 14q22.3, rs4813802 at 20p12.3, rs6687758 at $1 \mathrm{q} 41$, and rs174537 at 11q12.2, and CRC risk that may be modified with smoking in CRC carcinogenesis. Further gene-smoking interaction studies with large sample sizes are warranted to confirm our findings.

\section{Additional files}

Additional file 1: Questionnaire we used. (PDF 89 kb)

Additional file 2: Table S1. (Previously identified colorectal cancer susceptibility single-nucleotide polymorphisms by GWAS) and Table S2. (Table S2. Associations between GWAS-identified single-nucleotide polymorphisms and risk of colorectal cancer). (DOCX 73 kb)

\section{Abbreviations}

95\% Cls: 95\% confidence intervals; BMI: Body mass index; BMP: Bone morphogenetic protein; COX-2: Cyclooxygenase-2; CRA: Colorectal adenoma; CRC: Colorectal cancer; DUSP10: Dual specificity phosphatase 10; eQTL: Expression quantitative trait locus; FDR: False discovery rate; GWAS: Genome-wide association studies; HWE: Hardy-Weinberg equilibrium; IRB: Institutional review board; MAPK: Mitogen-activated protein kinase; NCC: National Cancer Center; ORs: Odds ratios; PAH: Polycyclic aromatic hydrocarbons; SNPs: Single-nucleotide polymorphisms; TGF $\beta$ : Transforming growth factor- $\beta$
\end{abstract}

\section{Acknowledgements}

Not applicable

\section{Funding}

This research was supported by the Basic Science Research Program through the National Research Foundation of Korea (2009-0093820, 2010-0010276, 2013R1A1A2A10008260) and the National Cancer Center Korea (0910220, $1,210,141)$. All funding bodies did not have a role in the study design, collection, analysis, interpretation of data, and writing manuscript.

\section{Availability of data and materials}

The datasets generated during and/or analysed during the current study are available from the corresponding author on reasonable request.

\section{Authors' contributions}

NS made contributions to conception and design, analyzed the data, interpreted the results, and was a major contributor in writing the manuscript. AS made contributions to conception and design, interpreted the results, involved in writing and revising manuscript, and gave final approval of the manuscript. HSJ made contributions to analysis, interpretation of data, and writing draft. JHO made substantial contributions to acquisition of data and revised the manuscript critically. JK was involved in interpretation of data and revising the manuscript critically for important intellectual content. All authors read and approved the final manuscript and agreed to be accountable for all aspects of the work.

\section{Ethics approval and consent to participate}

All participants provided written informed consent and the study was approved by the institutional review board of the NCC (IRB No. NCCNCS-10-350 and NCC 2015-0202)

\section{Consent for publication}

Not applicable

\section{Competing interests}

The authors declare that they have no competing interests.

\section{Publisher's Note}

Springer Nature remains neutral with regard to jurisdictional claims in published maps and institutional affiliations.

\section{Author details}

${ }^{1}$ Cancer Research Institute, Seoul National University College of Medicine, Seoul, South Korea. 'Department of Preventive Medicine, Seoul National University College of Medicine, 103 Daehak-ro, Jongno-gu, Seoul 03080, South Korea. ${ }^{3}$ Molecular Epidemiology Branch, National Cancer Center, Goyang, South Korea. ${ }^{4}$ Center for Colorectal Cancer, National Cancer Center, Goyang, South Korea. ${ }^{5}$ Molecular Epidemiology Branch, Division of Cancer Epidemiology and Prevention, Research Institute, National Cancer Center, 323 Ilsan-ro, Insandong-gu, Goyang-si, Gyeonggi-do 10408, South Korea.

Received: 13 July 2016 Accepted: 8 December 2017

Published online: 19 December 2017

\section{References}

1. Gandini S, Botteri E, lodice S, Boniol M, Lowenfels AB, Maisonneuve P, Boyle P. Tobacco smoking and cancer: a meta-analysis. Int J Cancer. 2008;122(1): 155-64.

2. Schaal C, Chellappan SP. Nicotine-mediated cell proliferation and tumor progression in smoking-related cancers. Mol Cancer Res. 2014;12(1):14-23.

3. Jensen K, Afroze S, Munshi MK, Guerrier M, Glaser SS. Mechanisms for nicotine in the development and progression of gastrointestinal cancers. Transl Gastrointest Cancer. 2012;1(1):81-7.

4. Cogliano VJ, Baan R, Straif K, Grosse Y, Lauby-Secretan B, El Ghissassi F, Bouvard V, Benbrahim-Tallaa L, Guha N, Freeman C, et al. Preventable exposures associated with human cancers. J Natl Cancer Inst. 2011;103(24): 1827-39.

5. Raimondi S, Botteri E, lodice S, Lowenfels AB, Maisonneuve P. Genesmoking interaction on colorectal adenoma and cancer risk: review and meta-analysis. Mutat Res. 2009:670(1-2):6-14.

6. Welter D, MacArthur J, Morales J, Burdett T, Hall P, Junkins H, Klemm A, Flicek P, Manolio T, Hindorff L, et al. The NHGRI GWAS catalog, a curated resource of SNP-trait associations. Nucleic Acids Res. 2014;42(Database issue):D1001-6.

7. Hutter CM, Chang-Claude J, Slattery ML, Pflugeisen BM, Lin Y, Duggan D, Nan H, Lemire M, Rangrej J, Figueiredo JC, et al. Characterization of geneenvironment interactions for colorectal cancer susceptibility loci. Cancer Res. 2012;72(8):2036-44.

8. Gong J, Hutter CM, Newcomb PA, Ulrich CM, Bien SA, Campbell PT, Baron JA, Berndt SI, Bezieau S, Brenner H, et al. Genome-wide interaction analyses between genetic variants and alcohol consumption and smoking for risk of colorectal cancer. PLoS Genet. 2016;12(10):e1006296.

9. Siegert S, Hampe J, Schafmayer C, von Schonfels W, Egberts JH, Forsti A Chen B, Lascorz J, Hemminki K, Franke A, et al. Genome-wide investigation of gene-environment interactions in colorectal cancer. Hum Genet. 2013; 132(2):219-31.

10. Simonds NI, Ghazarian AA, Pimentel CB, Schully SD, Ellison GL, Gillanders EM, Mechanic LE. Review of the gene-environment interaction literature in cancer: what do we know? Genet Epidemiol. 2016;40(5):356-65.

11. Song N, Shin A, Park JW, Kim J, JH O. Common risk variants for colorectal cancer: an evaluation of associations with age at cancer onset. Sci Rep. 2017:7:40644.

12. Woo H, Lee J, Lee J, Park JW, Park S, Kim J, JH O, Shin A. Diabetes mellitus and site-specific colorectal cancer risk in Korea: a case-control study. Journal of preventive medicine and public health = Yebang Uihakhoe chi. 2016; 49(1):45-52.

13. Han C, Shin A, Lee J, Lee J, Park JW, JH O, Kim J. Dietary calcium intake and the risk of colorectal cancer: a case control study. BMC Cancer. 2015;15:966.

14. Kweon S, Kim Y, Jang MJ, Kim Y, Kim K, Choi S, Chun C, Khang YH, Oh K. Data resource profile: the Korea National Health and nutrition examination survey (KNHANES). Int J Epidemiol. 2014;43(1):69-77.

15. Houlston RS, Cheadle J, Dobbins SE, Tenesa A, Jones AM, Howarth K, Spain SL, Broderick P, Domingo E, Farrington S, et al. Meta-analysis of three genomewide association studies identifies susceptibility loci for colorectal cancer at 1q41, 3q26.2, 12q13.13 and 20q13.33. Nat Genet. 2010;42(11):973-7.

16. Jia WH, Zhang B, Matsuo K, Shin A, Xiang YB, Jee SH, Kim DH, Ren Z, Cai Q, Long J, et al. Genome-wide association analyses in east Asians identify new susceptibility loci for colorectal cancer. Nat Genet. 2013;45(2):191-6. 
17. Cui R, Okada Y, Jang SG, JL K, Park JG, Kamatani Y, Hosono N, Tsunoda T, Kumar $V$, Tanikawa $C$, et al. Common variant in 6q26-q27 is associated with distal colon cancer in an Asian population. Gut. 2011;60(6):799-805.

18. Tomlinson I, Webb E, Carvajal-Carmona L, Broderick P, Kemp Z, Spain S, Penegar S, Chandler I, Gorman M, Wood W, et al. A genome-wide association scan of tag SNPs identifies a susceptibility variant for colorectal cancer at 8q24.21. Nat Genet. 2007;39(8):984-8.

19. Tenesa A, Farrington SM, Prendergast JG, Porteous ME, Walker M, Haq N, Barnetson RA, Theodoratou E, Cetnarskyj R, Cartwright N, et al. Genome-wide association scan identifies a colorectal cancer susceptibility locus on 11q23 and replicates risk loci at 8q24 and 18q21. Nat Genet. 2008;40(5):631-7.

20. Zanke BW, Greenwood CM, Rangrej J, Kustra R, Tenesa A, Farrington SM, Prendergast J, Olschwang S, Chiang T, Crowdy E, et al. Genome-wide association scan identifies a colorectal cancer susceptibility locus on chromosome 8q24. Nat Genet. 2007:39(8):989-94.

21. Tomlinson IP, Webb E, Carvajal-Carmona L, Broderick P, Howarth K, Pittman AM, Spain S, Lubbe S, Walther A, Sullivan K, et al. A genome-wide association study identifies colorectal cancer susceptibility loci on chromosomes 10p14 and 8q23.3. Nat Genet. 2008;40(5):623-30.

22. Zhang B, Jia WH, Matsuda K, Kweon SS, Matsuo K, Xiang YB, Shin A, Jee SH, Kim DH, Cai Q, et al. Large-scale genetic study in east Asians identifies six new loci associated with colorectal cancer risk. Nat Genet. 2014;46(6):533-42.

23. Jiao S, Hsu L, Berndt S, Bezieau S, Brenner H, Buchanan D, Caan BJ, Campbell PT, Carlson CS, Casey G, et al. Genome-wide search for gene-gene interactions in colorectal cancer. PLoS One. 2012;7(12):e52535.

24. Study C, Houlston RS, Webb E, Broderick P, Pittman AM, Di Bernardo MC, Lubbe S, Chandler I, Vijayakrishnan J, Sullivan K, et al. Meta-analysis of genome-wide association data identifies four new susceptibility loci for colorectal cancer. Nat Genet. 2008;40(12):1426-35.

25. Peters U, Jiao S, Schumacher FR, Hutter CM, Aragaki AK, Baron JA, Berndt SI, Bezieau S, Brenner H, Butterbach K, et al. Identification of genetic susceptibility loci for colorectal tumors in a genome-wide meta-analysis. Gastroenterology. 2013;144(4):799-807. e724

26. Botteri E, lodice S, Bagnardi V, Raimondi S, Lowenfels AB, Maisonneuve P. Smoking and colorectal cancer: a meta-analysis. JAMA. 2008;300(23):2765-78.

27. Otani T, Iwasaki M, Yamamoto S, Sobue T, Hanaoka T, Inoue M, Tsugane S, Japan Public Health Center-based Prospective Study G. Alcohol consumption, smoking, and subsequent risk of colorectal cancer in middle-aged and elderly Japanese men and women: Japan public health center-based prospective study. Cancer Epidemiol Biomark Prev. 2003;12(12):1492-500.

28. Sandler RS, Sandler DP, Comstock GW, Helsing KJ, Shore DL. Cigarette smoking and the risk of colorectal cancer in women. J Natl Cancer Inst. 1988:80(16):1329-33.

29. Potter JD. Colorectal cancer: molecules and populations. J Natl Cancer Inst 1999;91(11):916-32.

30. Martinez F, Fernandez-Martos C, Quintana MJ, Castells A, Llombart A, Iniguez F, Guillem V, Dasi F. APC and KRAS mutations in distal colorectal polyps are related to smoking habits in men: results of a cross-sectional study. Clin Transl Oncol. 2011;13(9):664-71.

31. Sarebo M, Skjelbred CF, Breistein R, Lothe IM, Hagen PC, Bock G, Hansteen $\mathrm{IL}$, Kure EH. Association between cigarette smoking, APC mutations and the risk of developing sporadic colorectal adenomas and carcinomas. BMC Cancer. 2006;6:71.

32. Yoshida K, Osawa K, Kasahara M, Miyaishi A, Nakanishi K, Hayamizu S, Osawa Y, Tsutou A, Tabuchi Y, Shimada E, et al. Association of CYP1A1, CYP1A2, GSTM1 and NAT2 gene polymorphisms with colorectal cancer and smoking. Asian Pac J Cancer Prev. 2007:8(3):438-44

33. Hansen RD, Krath BN, Frederiksen K, Tjonneland A, Overvad K, Roswall N, Loft S, Dragsted LO, Vogel U, Raaschou-Nielsen O. GPX1 pro(198)Leu polymorphism, erythrocyte GPX activity, interaction with alcohol consumption and smoking, and risk of colorectal cancer. Mutat Res. 2009; 664(1-2):13-9.

34. Smits KM, Gaspari L, Weijenberg MP, Dolzan V, Golka K, Roemer HC, Nedelcheva Kristensen V, Lechner MC, Mehling Gl, Seidegard J, et al. Interaction between smoking, GSTM1 deletion and colorectal cancer: results from the GSEC study. Biomarkers. 2003;8(3-4):299-310.

35. Ates NA, Tamer L, Ates C, Ercan B, Elipek T, Ocal K, Camdeviren H. Glutathione S-transferase M1, T1, P1 genotypes and risk for development of colorectal cancer. Biochem Genet. 2005;43(3-4):149-63.

36. van der Hel OL, Bueno de Mesquita HB, Roest M, Slothouber B, van Gils C, van Noord PA, Grobbee DE, Peeters PH. No modifying effect of NAT1,
GSTM1, and GSTT1 on the relation between smoking and colorectal cancer risk. Cancer Epidemiol Biomark Prev. 2003;12(7):681-2.

37. Yoshioka M, Katoh T, Nakano M, Takasawa S, Nagata N, Itoh H. Glutathione Stransferase (GST) M1, T1, P1, N-acetyltransferase (NAT) 1 and 2 genetic polymorphisms and susceptibility to colorectal cancer. J UOEH. 1999;21(2):133-47.

38. Gertig DM, Stampfer M, Haiman C, Hennekens CH, Kelsey K, Hunter DJ. Glutathione S-transferase GSTM1 and GSTT1 polymorphisms and colorectal cancer risk: a prospective study. Cancer Epidemiol Biomark Prev. 1998;7(11): 1001-5.

39. Liu L, Zhong R, Wei S, Xiang H, Chen J, Xie D, Yin J, Zou L, Sun J, Chen W, et al. The leptin gene family and colorectal cancer: interaction with smoking behavior and family history of cancer. PLoS One. 2013;8(4):e60777.

40. Zhong R, Chen X, Chen X, Zhu B, Lou J, Li J, Shen N, Yang Y, Gong Y, Zhu Y, et al. MAD1L1 Arg558His and MAD2L1 Leu84Met interaction with smoking increase the risk of colorectal cancer. Sci Rep. 2015:5:12202.

41. Robien K, Curtin K, Ulrich CM, Bigler J, Samowitz W, Caan B, Potter JD, Slattery ML. Microsomal epoxide hydrolase polymorphisms are not associated with colon cancer risk. Cancer Epidemiol Biomark Prev. 2005; 14(5):1350-2.

42. Lilla C, Verla-Tebit E, Risch A, Jager B, Hoffmeister M, Brenner H, ChangClaude J. Effect of NAT1 and NAT2 genetic polymorphisms on colorectal cancer risk associated with exposure to tobacco smoke and meat consumption. Cancer Epidemiol Biomark Prev. 2006;15(1):99-107.

43. van der Hel OL, Bueno de Mesquita HB, Sandkuijl L, van Noord PA, Pearson PL, Grobbee DE, Peeters PH. Rapid N-acetyltransferase 2 imputed phenotype and smoking may increase risk of colorectal cancer in women (Netherlands). Cancer Causes Control. 2003;14(3):293-8.

44. Peng XE, Jiang YY, Shi XS, ZJ H. NQO1 609C>T polymorphism interaction with tobacco smoking and alcohol drinking increases colorectal cancer risk in a Chinese population. Gene. 2013;521(1):105-10.

45. Han M, Wu G, Sun P, Nie J, Zhang J, Li Y. Association of genetic polymorphisms in PTEN and additional interaction with alcohol consumption and smoking on colorectal cancer in Chinese population. Int $J$ Clin Exp Med. 2015;8(11):21629-34.

46. Zhong R, Liu L, Zou L, Sheng W, Zhu B, Xiang H, Chen W, Chen J, Rui R, Zheng $X$, et al. Genetic variations in the TGFbeta signaling pathway, smoking and risk of colorectal cancer in a Chinese population. Carcinogenesis. 2013;34(4):936-42.

47. Sharafeldin N, Slattery ML, Liu Q, Franco-Villalobos C, Caan BJ, Potter JD, Yasui Y. A candidate-pathway approach to identify gene-environment interactions: analyses of colon cancer risk and survival. J Natl Cancer Inst. 2015;107(9). doi:10.1093/jnci/djv160.

48. Nishanian TG, Kim JS, Foxworth A, Waldman T. Suppression of tumorigenesis and activation of Wnt signaling by bone morphogenetic protein 4 in human cancer cells. Cancer Biol Ther. 2004;3(7):667-75.

49. Zhao L, Wang J, Wang L, Liang YT, Chen YQ, WJ L, Zhou WL. Remodeling of rat pulmonary artery induced by chronic smoking exposure. J Thorac Dis. 2014;6(6):818-28.

50. Kim DH, Liu J, Bhat S, Benedict G, Lecka-Czernik B, Peterson SJ, Ebraheim NA, Heck BE. Peroxisome proliferator-activated receptor delta agonist attenuates nicotine suppression effect on human mesenchymal stem cellderived osteogenesis and involves increased expression of heme oxygenase-1. J Bone Miner Metab. 2013:31(1):44-52.

51. Pabst $\mathrm{O}$, Zweigerdt $\mathrm{R}$, Arnold $\mathrm{HH}$. Targeted disruption of the homeobox transcription factor $\mathrm{Nkx2-3}$ in mice results in postnatal lethality and abnormal development of small intestine and spleen. Development. 1999; 126(10):2215-25

52. Massague J. How cells read TGF-beta signals. Nat Rev Mol Cell Biol. 2000; $1(3): 169-78$.

53. Tomlinson IP, Carvajal-Carmona LG, Dobbins SE, Tenesa A, Jones AM, Howarth K, Palles C, Broderick P, Jaeger EE, Farrington S, et al. Multiple common susceptibility variants near BMP pathway loci GREM1, BMP4, and BMP2 explain part of the missing heritability of colorectal cancer. PLOS Genet. 2011;7(6):e1002105.

54. Png CW, Weerasooriya M, Guo J, James SJ, Poh HM, Osato M, Flavell RA Dong $C$, Yang $H$, Zhang Y. DUSP10 regulates intestinal epithelial cell growth and colorectal tumorigenesis. Oncogene. 2016;35(2):206-17.

55. Ouyang W, Ma Q, Li J, Zhang D, Ding J, Huang Y, Xing MM, Huang C. Benzo[a]pyrene diol-epoxide (B[a]PDE) upregulates COX-2 expression through MAPKs/AP-1 and IKKbeta/NF-kappaB in mouse epidermal Cl41 cells. Mol Carcinog. 2007;46(1):32-41. 
56. Chan AT, Giovannucci EL. Primary prevention of colorectal cancer. Gastroenterology. 2010;138(6):2029-43. e2010

57. Kantor ED, Hutter CM, Minnier J, Berndt SI, Brenner H, Caan BJ, Campbell PT, Carlson CS, Casey G, Chan AT, et al. Gene-environment interaction involving recently identified colorectal cancer susceptibility loci. Cancer Epidemiol Biomark Prev. 2014;23(9):1824-33.

58. Kocarnik JD, Hutter CM, Slattery ML, Berndt SI, Hsu L, Duggan DJ, Muehling J, Caan BJ, Beresford SA, Rajkovic A, et al. Characterization of 9p24 risk locus and colorectal adenoma and cancer: gene-environment interaction and meta-analysis. Cancer Epidemiol Biomark Prev. 2010;19(12):3131-9.

59. Lubbe SJ, Di Bernardo MC, Broderick P, Chandler I, Houlston RS. Comprehensive evaluation of the impact of 14 genetic variants on colorectal cancer phenotype and risk. Am J Epidemiol. 2012;175(1):1-10

60. von Holst S, Picelli S, Edler D, Lenander C, Dalen J, Hjern F, Lundqvist N, Lindforss U, Pahlman L, Smedh K, et al. Association studies on 11 published colorectal cancer risk loci. Br J Cancer. 2010;103(4):575-80.

61. Khang $\mathrm{YH}$, Cho HJ. Socioeconomic inequality in cigarette smoking: trends by gender, age, and socioeconomic position in South Korea, 1989-2003. Prev Med. 2006;42(6):415-22.

\section{Submit your next manuscript to BioMed Central} and we will help you at every step:

- We accept pre-submission inquiries

- Our selector tool helps you to find the most relevant journal

- We provide round the clock customer support

- Convenient online submission

- Thorough peer review

- Inclusion in PubMed and all major indexing services

- Maximum visibility for your research

Submit your manuscript at www.biomedcentral.com/submit 